\title{
Effect of Feeding of Bypass Fat Mineral Mixture on Productive Performance and Quality of Milk of Buffaloes in Armori Tahsil
}

\author{
V.G. Atkare, A.D. Shambharkar and S.M. Khupse* \\ Animal Husbandry and Dairy Science, College of Agriculture Nagpur, India \\ *Corresponding author
}

\section{Keywords}

Bypass fat mineral mixture Productive performance, Quality of milk, Buffaloes

Article Info

Accepted:

26 December 2017

Available Online:

10 January 2018

\section{A B S T R A C T}

The present investigation was carried out at Armori Tahsil of Gadchiroli Dist. during the year 2016-17 under sanctioned project by the Ministry of Science and Technology, Department of Biotechnology, New Delhi entitled as "Hope generation in livestock owners of tribal area under two blocks of Gadchiroli district through training and demonstration of scientific livestock management practices" to the Section of Animal Husbandry and Dairy Science, College of Agriculture, Nagpur. Dairy Farming Practices Adopted For Buffaloes Around Armori Tahsil, were evaluated in project implementing areas of Armori Tahsil of Gadchiroli Dist. Five villages namely, Thanegaon, Shivani, Waghada, Deulgaon and Akapur were randomly selected. The data on productive performance and quality of milk was collected by contacting with 200 buffalo owners and chemical quality in terms of fat, SNF and TS percentage in milk of buffaloes were evaluated and analysed statistically to see the productive performance and to know the chemical quality of milk. Average maximum weekly milk yield was recorded in Thanegaon village $(59.28 \pm 0.69)$ and minimum in the Akapur village (58.87 \pm 0.84 ) buffaloes supplemented with Bypass fat mineral mixture. Average maximum weekly milk yield performance showing increasing trend with respect to weekly milk yield for a period of eight weeks from $1^{\text {st }}$ to $8^{\text {th }}$ week with peak milk yield was (63.60 lit.). Thereafter declining trend was upto $12^{\text {th }}$ week of lactation. In relation to chemical quality the overall fat, SNF and TS were recorded as 8.44 $\%, 9.59 \%$ and $18.02 \%$ respectively. These three components in milk of buffaloes were greatly affected due to supplemented with Bypass fat mineral mixture in different selected villages. The results indicated that the milk production increased all selected village due to supplementation of Bypass fat mineral mixture. The chemical quality of milk of buffaloes in terms of fat, SNF and TS percentage also improved.

\section{Introduction}

Energy density of the diet can be increased by fat supplementation but high dietary fat results in the reduction of fibre digestion in the rumen and a decline in milk fat percentage
(Palmquist and Jenkins, 1980). Bypass fat supplementation in the ration of lactating animal, enhances the energy intake and reduces the adverse effect of NEBAL during early lactation (Drackley, 1999) without affecting rumen cellulolytic bacterial activity (Thakur and Shelke, 2010). Unprotected fats 
cause physical and chemical changes in the microbial fermentation of feed and depress rumen cellulolytic microbial activity (Palmquist, 1991). So the feeding of rumen inert fat is partially resistant to biohydrogenation by the rumen microbes and reduces risk of metabolic acidosis (Naik, 2013). Adding protected fat to dairy rations can positively affect the efficiency of dairy cows through a combination of calorific effect and non-calorific effects (Tyagi et al., 2010).

Most of the animals in developing countries including India are fed on agriculture byproducts and low quality crop residues, which have got low inherent low nutritive value and digestibility. High producing buffaloes in early lactation do not consume sufficient dry matter to support maximal production of milk (Goff and Horst, 1997). Demand for energy is very high during early stage of lactation but supply is not commensurate with demand due physiological stage or limited intake may affects production potential of animal in the whole lactation length (Sirohi et al., 2010).

The beginning of lactation is one of the most crucial periods in the lactation cycle of dairy animals. Despite having access to high energy diet ad-libitum, most dairy animals go through a period of negative energy balance, particularly during the first trimester of lactation. The process allows much higher production by changing energy flow so as to partition more energy to milk and less to body reserves for a longer period during lactation. Therefore nutritional management during this period is crucial for the productivity of dairy animals. Dairy animals mobilize large amounts of fatty acids, also known as nonesterified fatty acids (NEFA), from adipose tissue to meet their energy requirement during early lactation, resulting in increased circulating concentrations of NEFA in the bloodstream. Supplementation with calcium salts of long chain fatty acids is a good method for increasing energy density of the diet to improve productive performances (Garg et al., 2012).

Bypass fats are commonly referred to as ruminal inert fat, protected fat and escape fat and are more expensive per unit of energy provided compared to commodity fats. Calcium salts of fatty acids increase milk yield and fat contents but partially degrade in the abomasum. Prill fat, a bypass fat is available in different forms and augments productive performance of lactating animals by getting digested in the small intestine (Sing et al., 2015).

Cereal grains and fats plays an important role as source of energy in the ration of high yielding dairy animals for optimum productivity but due to use of cereals for human consumption and monogastric animals the alternate source of energy in dairy ration is supplemental fat (Saijpaul et al., 2010).

Bypass fat comprises fatty acid associated with calcium ions, instead of a glycerol backbone. When calcium is associated with fatty acids, the fat supplement thus formed is rumen inert. Bypass fat has low solubility in the rumen and is less susceptible to biohydrogenation. However, in abomasum at acidic $\mathrm{pH}$ it dissociates and set free fatty acids and calcium for absorption. Feeding bypass fat to early lactating animals increases milk and fat yield and ensures early conception. Keeping this in mind the above revelations an attempt was made to effect of feeding of bypass fat mineral mixture on productive performance and quality of milk of buffaloes in Armori tahsil

\section{Materials and Methods}

The study was carried out in Armori tahsil of Gadchiroli district during the year 2016 - 17 under sanctioned project by the Ministry of 
Science and Technology, Department of Biotechnology entitled as "Hope generation in livestock owners of tribal area under two blocks of Gadchiroli district through training and demonstration of scientific livestock Management practices" to the Section of Animal Husbandry and Dairy Science College of Agriculture, Nagpur. Five villages from Armori tahsil namely, Thanegaon, Shivani, Waghada, Deulgaon and Akakpur were randomly selected. The list of buffalo owners was prepared for each village with the help of Gramsevak and Livestock Development officers of Armori Panchayat Samiti. These buffalo owners were contacted from each village and accordingly total buffalo owners contacted were 200 i.e. 40 buffalo owners from each village contacted from Armori tahsil of Gadchiroli dist.

With a view to determining the chemical quality of milk of buffalos from selected villages, milk samples were collected from morning milking of buffalos. The first milk sample from each village per buffalo was collected after the period of colostrum milk period after calving was over. Thereafter, five samples of morning milk were collected at an interval of 5 days. Thus, in all 5 samples per buffalo were collected during each village and used for analysing various constituents of milk. The fat content in the milk during each village was determined by Gerber's method as described in IS: 1224 (part-I), (Anonymous, 1977). SNF content was calculated by using ISI lactometer and Total Solid content was calculated by addition of fat and SNF content in milk.

The data collected in respect of all above parameters were tabulated and subjected to statistical evaluation by adopting the standard technique prescribed by Panse and Sukhatme (1985). To find out mean, standard deviation and coefficient of variation so as to estimate the central value and the extent at variability in the data. The standard deviation and coefficient of variation was calculated by adopting the following formula.

$\sigma=\frac{\sqrt{\sum\left(X_{i}-\bar{X}\right)^{2}}}{n}$

Where,

$\sigma=$ Standard deviation

$\mathrm{X}_{\mathrm{i}}=$ Values of the variables

$\bar{X}=$ Mean

$\mathrm{N}=$ No. of observation of the series

Coefficient of variation was used to compare the magnitude of relative dispersion among the data of different variations.

C.V. $=\frac{\text { S. D. }}{\bar{X}^{-----} \times 100}$

Where,

C.V. = coefficient of variation

S.D. $=$ Standard Deviation

$\bar{X}=$ Mean

\section{Results and Discussion}

It is evident from the table 1 , that the overall average weekly milk yield of 26 buffaloes over a period of experimental period i.e. upto12 ${ }^{\text {th }}$ week of lactation was $46.31 \pm 0.68$ lit before feeding of bypass fat mineral mixture (BFMM).The corresponding figure of weekly average milk yield after supplementation of BFMM was $59.06 \pm 0.79$ lit.

Maximum milk yield was recorded in Thanegaon village $(59.28 \pm 0.691$.) followed by Deulgaon village $(59.14 \pm 0.80$ 1.), Shivani village (59.06 \pm 0.801 .), Waghada village (58.98 \pm 0.911 .) and Akapur village (58.87 \pm 0.84 
1), respectively with coefficient of variation $4.04,4.72,4.69,5.33$ and 4.90 respectively.

It was observed that average weekly milk yield of buffaloes before supplementation of BFMM was very less as compared the average weekly milk yield of buffaloes supplementation with BFMM over a experimental period.

It was noticed that average weekly milk yield showed inclined performance upto $8^{\text {th }}$ week of lactation in overall Armori tahsil. Maximum weekly milk yield recorded in village of Thanegaon $(59.28 \pm 0.69$ 1.) while minimum milk yield recorded in village of Akapur (58.87 \pm 0.84 1.)

After attaining the peak yield, the productive performance found as more or less constant for a period of four weeks i.e. $9^{\text {th }}$ to $12^{\text {th }}$ week with respect of average weekly milk yield in all selected villages (Thanegaon, Shivani, Waghada, Deulgaon and Akapur in Armori tahsil).

It was further noticed that in selected villages peak milk yield did recorded as more or less similar due to supplementation of Bypass fat mineral mixture. Pertaining to average weekly milk yield after supplementation BFMM after attending peak milk yield period, it was noticed that overall average milk yield increases up to $11^{\text {th }}$ week of lactation and thereafter declined $\left(59.421\right.$.) during $12^{\text {th }}$ week of lactation over an experimental period.

Garg et al., (2008) reported that feeding by pass fat supplement improved supply of amino acids in the presence of sufficient metabolizable energy, might have also improved the protein -energy balance and created a better balance of precursors for milk synthesis, resulting in increased milk production. The significant improvement in milk production performance could be due to the increased supply of amino acids at the tissue level. These findings are in line with the present investigation.

Garg et al., (2012) reported that on supplementing with bypass fat alone or with RPC in lactating Jaffarabadi buffaloes, the average increases in milk yield $(\mathrm{kg})$ were 1.26 $(\mathrm{p}<0.05)$ and $1.55(\mathrm{p}<0.01)$ in groups 2 and 3 , as compared to the control.

With increase in the unsaturation of the dominant fatty acids in $\mathrm{Ca}$ salts, milk yield increased linearly in early lactation of cow (Chouinard et al., 1998). Supplementation of bypass fat to lactating buffalo not only increases energy intake but also increase unsaturated fatty acid content of buffalo milk and more economic returns to dairy farmers (Parnerkar et al., 2010). Diets containing supplemental fat often stimulate increased milk production because of increased energy intake, improved efficiency of utilization of energy, or both (Maiga and Schingoethe, 1997).

On supplementation of bypass fat in the diet of dairy animals, the milk yield is increased by 5.5-24.0\% (Naik et al., 2009b; Tyagi et al., 2009a; Thakur and Shelke, 2010; Sirohi et al., 2010; Gowda et al., 2013; Parnerkar et al., 2011; Wadhwa et al., 2012). It was noticed that average weekly milk yield showed that Bypass fat supplementation at $1.4 \%$ of DMI $\left(200 \mathrm{~g} \mathrm{day}^{-1}\right)$ increased the milk production and feed efficiency in lactating Murrah buffaloes (Ranjan et al., 2012). There was an improvement of $6.02 \%$ in milk yield of early lactating crossbred cows fed $75 \mathrm{~g}$ day $^{-1}$ per animal PF (Rajesh, 2013). Likewise Similar amount of prill fat (PF) feeding to Murrah buffaloes resulted in $10 \%$ increase of milk yield in organized herd (Singh et al., 2015). These studies are in line with the result of present study. 
Table.1 Effect of feeding of BFMM on mean weekly milk yield (lit) of buffaloes

\begin{tabular}{|c|c|c|c|c|c|c|}
\hline \multirow[t]{2}{*}{ Weeks } & \multicolumn{4}{|c|}{ Selected Villages } & & \multirow[t]{2}{*}{ Average } \\
\hline & Thanegaon & Shivani & Waghada & Deulgaon & Akapur & \\
\hline \multirow[t]{2}{*}{$1^{\text {st }}$} & 44.17 & 43.20 & 44.25 & 44.50 & 43.30 & 43.88 \\
\hline & $(56.26)^{*}$ & $(55.20)$ & (52.44) & $(54.66)$ & $(53.16)$ & $(54.34)$ \\
\hline \multirow[t]{2}{*}{$2^{\text {nd }}$} & 42.22 & 42.56 & 41.70 & 42.62 & 41.55 & 42.13 \\
\hline & $(57.24)$ & $(56.35)$ & $(56.42)$ & $(56.75)$ & $(56.10)$ & (56.57) \\
\hline \multirow[t]{2}{*}{$3^{\text {rd }}$} & 43.50 & 43.72 & 43.80 & 44.15 & 43.50 & 43.73 \\
\hline & $(58.62)$ & (57.77) & $(58.30)$ & $(58.52)$ & $(57.65)$ & (58.17) \\
\hline \multirow[t]{2}{*}{$4^{\text {th }}$} & 44.27 & 44.50 & 44.36 & 43.86 & 44.24 & 44.25 \\
\hline & $(56.33)$ & (56.66) & (56.87) & (56.48) & $(57.11)$ & (56.69) \\
\hline \multirow[t]{2}{*}{$5^{\text {th }}$} & 45.23 & 46.15 & 45.66 & 46.21 & 45.81 & 45.81 \\
\hline & (57.65) & $(56.22)$ & (57.88) & $(56.95)$ & $(57.16)$ & (57.17) \\
\hline \multirow[t]{2}{*}{$6^{\text {th }}$} & 46.25 & 46.50 & 46.78 & 46.25 & 46.51 & 46.46 \\
\hline & $(58.12)$ & $(58.54)$ & $(58.11)$ & $(58.50)$ & (57.94) & (58.24) \\
\hline \multirow[t]{2}{*}{$7^{\text {th }}$} & 46.26 & 46.35 & 47.14 & 47.25 & 47.40 & 46.88 \\
\hline & $(59.23)$ & (59.55) & (59.10) & (58.90) & (59.78) & (59.31) \\
\hline \multirow[t]{2}{*}{$8^{\text {th }}$} & 48.55 & 48.62 & 48.86 & 48.25 & 49.55 & 48.77 \\
\hline & $(63.55)$ & (64.29) & (64.14) & (63.84) & (62.19) & (63.60) \\
\hline \multirow[t]{2}{*}{$9^{\text {th }}$} & 49.28 & 49.36 & 49.85 & 50.11 & 49.68 & 49.66 \\
\hline & $(62.32)$ & (61.59) & $(61.49)$ & (62.18) & $(62.41)$ & $(62.00)$ \\
\hline \multirow[t]{2}{*}{$10^{\text {th }}$} & 47.51 & 47.36 & 47.52 & 48.11 & 47.14 & 47.53 \\
\hline & $(62.18)$ & $(62.25)$ & (63.14) & $(62.45)$ & $(62.22)$ & $(62.45)$ \\
\hline \multirow[t]{2}{*}{$11^{\text {th }}$} & 48.57 & 48.24 & 48.81 & 49.14 & 49.22 & 48.80 \\
\hline & $(60.15)$ & $(60.45)$ & $(60.44)$ & (61.41) & $(61.55)$ & $(60.80)$ \\
\hline \multirow[t]{2}{*}{$12^{\text {th }}$} & 47.45 & 47.62 & 47.86 & 48.17 & 48.12 & 47.84 \\
\hline & (59.67) & (59.83) & (59.45) & (58.99) & $(59.15)$ & (59.42) \\
\hline \multirow[t]{2}{*}{ Avg. } & 46.11 & 46.18 & 46.38 & 46.55 & 46.34 & 46.31 \\
\hline & $(59.28)$ & (59.06) & (58.98) & (59.14) & (58.87) & $(59.06)$ \\
\hline \multirow[t]{2}{*}{ S.E. $( \pm)$} & 0.65 & 0.64 & 0.70 & 0.68 & 0.78 & 0.68 \\
\hline & $(0.69)$ & $(0.80)$ & $(0.91)$ & $(0.80)$ & $(0.84)$ & $(0.79)$ \\
\hline \multirow[t]{2}{*}{ C.V. } & 4.89 & 4.84 & 5.29 & 5.05 & 5.81 & 5.14 \\
\hline & (4.04) & $(4.69)$ & (5.33) & (4.72) & (4.9) & $(4.65)$ \\
\hline
\end{tabular}

* Denote Average milky yield after supplementation BFMM BFMM: By pass Fat Mineral Mixture 
Table.2 Chemical quality of milk in terms of fat $\%$ in milk of buffaloes under different selected villages

\begin{tabular}{|c|c|c|c|c|c|c|c|c|c|c|}
\hline Sr. & Selected & \multicolumn{3}{|c|}{ Fat \% } & \multicolumn{2}{|c|}{ S.E. $( \pm)$} & \multicolumn{3}{c|}{ C.V. } & \multicolumn{2}{|c|}{ S.D. } \\
\hline No. & Villages & Control & Final & Control & Final & Control & Final & Control & Final \\
\hline $\mathbf{1}$ & Thanegaon & 7.67 & 8.15 & 0.14 & 0.15 & 4.18 & 3.94 & 0.318 & 0.324 \\
\hline $\mathbf{2}$ & Shivani & 7.80 & 8.17 & 0.09 & 0.099 & 2.58 & 2.655 & 0.2 & 0.217 \\
\hline $\mathbf{3}$ & Waghada & 7.81 & 8.30 & 0.16 & 0.19 & 4.59 & 5.31 & 0.36 & 0.445 \\
\hline $\mathbf{4}$ & Deulgaon & 7.92 & 8.68 & 0.06 & 0.22 & 1.88 & 5.66 & 0.14 & 0.499 \\
\hline $\mathbf{5}$ & Akapur & 8.48 & 8.88 & 0.30 & 0.20 & 7.79 & 5.248 & 0.66 & 0.468 \\
\hline & Overall average & $\mathbf{7 . 9 4}$ & $\mathbf{8 . 4 4}$ & $\mathbf{0 . 1 5}$ & $\mathbf{0 . 1 7 2}$ & $\mathbf{4 . 2 0 4}$ & $\mathbf{4 . 5 6 3}$ & $\mathbf{0 . 3 3 6}$ & $\mathbf{0 . 3 9 1}$ \\
\hline
\end{tabular}

(Mean based on 5 milk samples)

Table.3 Chemical quality of milk in terms of SNF (solids not fat) \% in milk of buffaloes under different selected villages

\begin{tabular}{|c|c|c|c|c|c|c|c|c|c|c|}
\hline $\mathbf{S r}$ & Selected & \multicolumn{2}{|c|}{ SNF \% } & \multicolumn{2}{|c|}{ S.E. } \\
$\mathbf{N}$ & $\mathbf{\pm}$ & \multicolumn{2}{|c|}{ C.V. } & \multicolumn{2}{c|}{ S.D. } \\
\hline $\mathbf{1}$ & Villages & Control & Final & Control & Final & Control & Final & Control & Final \\
\hline $\mathbf{2}$ & Thanegaon & 9.32 & 9.44 & 0.09 & 0.14 & 2.2 & 3.42 & 0.207 & 0.329 \\
\hline $\mathbf{3}$ & Shivani & 9.71 & 9.54 & 0.087 & 0.077 & 1.9 & 1.68 & 0.18 & 0.16 \\
\hline $\mathbf{4}$ & Waghada & 9.69 & 9.62 & 0.089 & 0.05 & 2.071 & 1.30 & 0.20 & 0.123 \\
\hline $\mathbf{5}$ & Deulgaon & 9.65 & 9.59 & 0.084 & 0.062 & 1.913 & 1.494 & 0.183 & 0.147 \\
\hline & Akapur & 9.83 & 9.75 & 0.04 & 0.201 & 1.071 & 4.727 & 0.102 & 0.46 \\
\hline & Overall average & $\mathbf{9 . 6 4}$ & $\mathbf{9 . 5 9}$ & $\mathbf{0 . 0 7 8}$ & $\mathbf{0 . 1 0 6}$ & $\mathbf{1 . 8 3 1}$ & $\mathbf{2 . 5 2 4}$ & $\mathbf{0 . 1 7 4}$ & $\mathbf{0 . 2 4 4}$ \\
\hline
\end{tabular}

(Mean based on 5 milk samples)

Table.4 Chemical quality of milk in terms of TS (Total solid) \% in milk of buffaloes under different selected villages

\begin{tabular}{|c|c|c|c|c|c|c|c|c|c|c|}
\hline Sr. & Selected & \multicolumn{2}{|c|}{ TS\% } & \multicolumn{2}{|c|}{ S.E. $\mathbf{\pm}$} & \multicolumn{3}{c|}{ C.V. } & \multicolumn{2}{c|}{ S.D. } \\
\hline No. & Villages & Control & Final & Control & Final & Control & Final & Control & Final \\
\hline $\mathbf{1}$ & Thanegaon & 16.98 & 17.59 & 0.19 & 0.2 & 2.55 & 2.66 & 0.44 & 0.46 \\
\hline $\mathbf{2}$ & Shivani & 17.51 & 17.71 & 0.152 & 0.107 & 2.03 & 1.285 & 0.35 & 0.22 \\
\hline $\mathbf{3}$ & Waghada & 17.5 & 17.92 & 0.212 & 0.164 & 2.785 & 2.06 & 0.489 & 0.37 \\
\hline $\mathbf{4}$ & Deulgaon & 17.57 & 18.27 & 0.103 & 0.249 & 1.358 & 2.97 & 0.238 & 0.54 \\
\hline $\mathbf{5}$ & Akapur & 18.31 & 18.63 & 0.3 & 0.19 & 3.75 & 2.395 & 0.68 & 0.44 \\
\hline & Overall average & $\mathbf{1 7 . 5 7}$ & $\mathbf{1 8 . 0 2}$ & $\mathbf{0 . 1 9 1}$ & $\mathbf{0 . 1 8 2}$ & $\mathbf{2 . 4 9 5}$ & $\mathbf{2 . 2 7 4}$ & $\mathbf{0 . 4 3 9}$ & $\mathbf{0 . 4 0 6}$ \\
\hline
\end{tabular}

(Mean based on 5 milk samples)

\section{Chemical quality of milk}

Fat $(\%)$

It is seen from table 2, that the fat percentages in average weekly milk yield in Thanegaon, Shivani, Waghada, Deulgaon and Akapur in Armori tahsil with their standard error were recorded as $8.15 \pm 0.15,8.17 \pm 0.10,8.30 \pm 0.19$, $8.68 \pm 0.22$ and $8.88 \pm 0.20$ per cent, respectively. The overall average fat per cent in milk of buffaloes were recorded as $8.44 \pm 0.17$ per cent. The result showed that there was the increased in fat percentage in milk of buffaloes after supplementation BFMM, in Armori tahsil, while studying the effect of feeding bypass fat 
supplement on milk production and constituents of milk.

Garg et al., 2008 reported that significant effect of supplementing bypass fat on average weekly milk yield in lactating crossbred (HF x Jersey). The fat content increased from $3.90 \pm 0.65$ to $4.33 \pm 0.58 \quad(\mathrm{p}<0.05) \quad$ crossbred cows supplemented with bypass fat. Likewise significant effect of supplementing bypass fat on milk production and dairy fat yield in Holstein Frisian cows has been reported by past workers (Garg and Mehta 1998 and Garg et al., 2002a).

It is well known that, among all milk components fat is the most sensitive variable to dietary changes. An increase in the proportion of LCFA (C18:1, C18:2, C18:3) takes place due to more uptake of preformed LCFA from blood (Mishra et al., 2004). The supplementation of bypass fat increases milk fat in lactating cows (Fahey et al., 2002; Purushothaman et al., 2008; Rajesh, 2013; Yadav et al., 2015). These findings are in line with the present investigation.

There was significant $(p<0.001)$ improvement in milk fat percent and fat yield due to feeding of calcium salt of palm oil fatty acids. The milk fat percent was $7.75 \pm 0.02$ in BYFAT group which was more compared to that of $7.18 \pm 0.03$ in CON animals (Vahora et al., 2013).

\section{SNF (solids not fat-\%)}

It is evident from table 3, that the SNF per cent in milk of buffaloes in selected villages namely, Thanegaon, Shivani, Waghada, Deulgaon and Akapur in Armori tahsil were recorded as $9.44 \pm 0.14,9.54 \pm 0.08,9.62 \pm 0.05,9.59 \pm 0.06$ and $9.75 \pm 0.20$ per cent, respectively. The overall SNF percentage in milk of buffaloes was recorded as $9.59 \pm 0.11$ with standard deviation 0.24 and coefficient of variation 2.52. Average maximum SNF per cent $(9.75 \pm 0.20 \%)$ was recorded in Akapur village fallowed by Waghada village $(9.62 \pm 0.05 \%)$, Deulgaon $(9.59 \pm 0.06 \%)$, Shivani $(9.54 \pm 0.08 \%)$, and
Thanegaon (9.44 $\pm 0.14 \%)$, respectively. From table 3, the SNF content of milk is not altered by supplementing BFMM to lactating buffaloes. Naik et al., 2009b reported that SNF content of milk of crossbred dairy cows not altered by feeding indigenously prepared rumen protected fat The present investigation are also in line with Thakur and Shelke, 2010; Sirohi et al., 2010. However, the total SNF yield is increased due to the increase in milk production (Naik et al., 2009b).

\section{TS (Total solids) \%}

From table 4, it is seen that the total solid percentage in milk of buffaloes in Thanegaon, Shivani, Waghada, Deulgaon and Akapur in Armori tahsil was as $17.59 \pm 0.20,17.71 \pm 0.11$, $17.92 \pm 0.16,18.27 \pm 0.25$ and $18.63 \pm 0.19$ per cent respectively. Average maximum TS per cent $(18.63 \pm 0.19 \%)$ was recorded in Akapur village fallowed by Deulgaon village $(18.27 \pm 0.25 \%)$, Waghada village $(17.92 \pm 0.16 \%)$, Shivani village $(17.51 \pm 0.11 \%)$ and Thanegaon village $(17.59 \pm 0.20 \%)$, respectively.

Atkare and Khupse, 2016 reported that feeding of bypass fat mineral mixture fed to lactating crossbred cows have greater milk yield than control feed while pertaining to milk quality they notice that feed supplement was no effect on milk quality but supplementation leads to increase the components in milk such as fat and Total solids while SNF remains unaffected. These findings are supportive to the results of present study.

The present investigation revealed that the chemical composition in terms of fat and TS percentage was significantly affected due to supplementation of Bypass fat mineral mixture. Supplementation of bypass fat improves the energy balance of lactating buffaloes and significantly increase milk volume as well as modify composition of fat and TS of milk in buffaloes on feeding of bypass fat mineral mixture on productive performance and quality of milk of Buffaloes. 
SNF percentage in milk of buffaloes remained unaffected by the lactation numbers. Therefore, the results from present study suggested that the buffaloes should be provided feeding of bypass fat mineral mixture (BFMM), quality nutrition and protection from the environmental condition for maintaining calving pattern, rate of milk production in every lactation and chemical quality of milk.

\section{References}

Anonymous, 1977. Determination of fat by Gerber's method.IS 1224.Part 1, First revision. Bureau of Indian Standards, Manak Bhavan, New Delhi.

Atkare, V.G. and S.M. Khupse 2016. Effect of feeding of bypass fat mineral mixture on productive performance and quality of milk of crossbred cows in Armori tahsil. Advances in life Sci. 5(22):10380-10384.

Chouinard, P.Y., V. Girard and G.J. Brisson, 1998. Fatty acid profile and physical properties of milk fat from cows fed calcium salts of fatty acids with varying unsaturation. J. Dairy Sci., 81: 471-481.

Drackley, J.K. 1999. Biology of dairy cows during the transition period; the final frontier. J. of Dairy Sciences, 82: 22592273.

Fahey, J., J.F. Mee, J.J. Murphy and D. O'Callaghan, 2002. Effects of calcium salts of fatty acids and calcium salts of methionine hydroxy analogue on plasma prostaglandin $\mathrm{F}_{2 \alpha}$ metabolite and milk fatty acid profiles in late lactation Holstein-Friesian cows. Theriogenology, 58: 1471-1482.

Garg, M.R. and Mehta, A.K 1998. Effect of feeding Bypass fat on feed intake, milk production and body condition of Holstein Friesian cows. Indian J. Anim. Nutr. 15:242-245.

Garg, M.R., B.M. Bhanderi and P.L. Sherasia, 2008. Effect of supplementing bypass fat with rumen protected choline chloride on milk yield, milk composition and metabolic profile in crossbred cows. Indian J. Dairy Sci., 65: 319-323.
Garg, M.R., P.L. Sherasia and B.M. Bhanderi, 2012. Effect of Supplementing Bypass fat with and without rumen protected choline chloride on milk yield and serum lipid profile in Jaffarabadi Buffaloes. Buffalo Bulletin, 31(2):91-98.

Garg, M.R., Sherasia, PL., Bhanderi, B.M., Gulati, S.K and Scott, T.W. 2002a. Efect of feeding rumen protected nutrients on milk production in crossbred cows. Indain J.Anim.Nutr.19:191-198.

Goff, J.P. and R.L. Horst 1997. Effect of the addition of potassium or sodium, but not calcium, to prepartum rations on milk fever in dairy cows. J. of Dairy Sci., 80:176-186.

Gowda, N.K.S., A. Manegar, A. Raghavendra, S. Verma and G. Maya et al., 2013. Effect of protected fat supplementation to high yielding dairy cows in field condition. Anim. Nutr. Feed Technol., 13: 125-130.

Maiga, H.A. and Schingoethe D.J. 1997. Optimizing the utilization of animal fat and ruminal bypass proteins in the diets of lactating dairy cows. J. of Dairy Sci., 80:343-352.

Mishra, S., S.S. Thakur and K. Rakesh, 2004. Milk production and composition in crossbred cows fed calcium salts of mustard oil fatty acids. Indian J. Anim. Nutr., 21:22-25.

Naik, P.K. 2013. Benefits and scope of indigenously prepared bypass fat. Indian Dairyman, February Issue, pp. 66-68.

Naik, P.K., Saijpaul, S., Sirohi, A.S. and Raquib, M. 2009b. Lactation response of crossbred dairy cows fed indigenously prepared rumen protected fat - Afield trial. Indian J. of Animal Sci., 79: 10451049.

Palmquist, D.L. 1991. Influence of source and amount of dietary fat on digestibility in lactating cows. J. of Dairy Science, 74: 1354-1360.

Palmquist, D.L. and Jenkins, T.C. 1980. Fat in lactation rations: Review. J. of Dairy Science, 63: 1-14.

Panse, V. G. and P. V. Sukhatme, 1985. Statistical methods for agricultural 
workers, I. C. A. R., New Delhi.

Parnerkar S., D. Kumar, S.S. Shankhpal and H. Thube 2010. Effect of feeding bypass fat to lactating buffaloes during early lactation. Pp. 126-131 in Proc. of $7^{\text {th }}$ Biennial Anim. Nutr. Asso. Conf., Orissa Univ. Agric. and Technol. Bhubneshwar, India.

Parnerkar S., D. Kumar, S.S. Shankhpal and Thube, Marshala, 2011. Effect of feeding bypass fat to lactating buffaloes during early lactation. In Proceedings of 14 th Biennial Conference of Anim. Nutr. Society of India 'Livestock Productivity Enhancement with Available Feed Resources', Nov. 3-5, 2011, Pantnagar, India, pp. 111-112.

Purushothaman, S., A. Kumar and D.P. Tiwari, 2008. Effect of feeding calcium salts of palm oil fatty acids on performance of lactating crossbred cows. Asian-Aust. J. Anim. Sci., 13(21):376-385.

Rajesh, G., 2013. Studies on postpartum physiological adaptation in hormones, metabolites and milk production in crossbred cows fed with prill fat. M.V.Sc Thesis, NDRI Deemed University, Karnal, Haryana, India.

Ranjan, A., B. Sahoo, V.K. Singh, S. Srivastava, S.P. Singh and A.K. Pattanaik, 2012. Effect of bypass fat supplementation on productive performance and blood biochemical profile in lactating Murrah (Bubalus bubalis) buffaloes. Trop. Anim. Health Prod., 44: 1615-1621.

Saijpaul S., Naik P.K. and Neelam R. (2010). Effects of rumen protected fat on in vitro dry matter degradability of dairy rations. Indian J. Anim. Sci. 80, 993- 997
Sing, Mahendra., A.K.Roy and Shikha Sharama 2015. Augmentation of milk production by supplementing bypass fat in dairy animals. Asian J.Anim.Vet.Adv., 10 (9):476-488.

Sirohi, S.K., T.K. Walli and R.K. Mohanta. 2010. Supplementation effect of bypass fat on production performance of lactating crossbred cows. Indian J. Anim. Sci. 80:733-736.

Thakur, S.S. and Shelke S.K. 2010. Effect of supplementing bypass fat prepared from soybean acid oil on milk yield and nutrient utilization in Murrah buffaloes. Indian J. of Anim. Sci., 80: 354-357.

Tyagi, N., S.S. Thakur and S.K. Shelke, 2009a. Effect of feeding bypass fat supplement on milk yield, its composition and nutrient utilization in crossbred cows. Indian J. of Anim. Nutr., 26: 1-8.

Tyagi, N., S.S. Thakur and S.K. Shelke, 2010. Effect of bypass fat supplementation on productive and reproductive performance in crossbred cows. Trop. Anim. Health Prod., 42: 1749-1755.

Vahora, S.G., S. Parnerkar and K.B. More 2013. Productive efficiency of lactating buffaloes fed bypass fat under field conditions: Effect on milk yield, Milk Composition, Body Weight and Economics.

Wadhwa, M., R.S. Grewal, M.P.S. Bakshi and P.S. Brar, 2012. Effect of supplementing bypass fat on the performance of high yielding crossbred cows. Indian J. Anim. Sci., 82:200-203.

Yadav, G., A.K. Roy and M. Singh, 2015. Effect of prilled fat supplementation on milk production performance of crossbred cows. Indian J. Anim. Nutr., 32: 133-138.

\section{How to cite this article:}

Atkare, V.G., A.D. Shambharkar and Khupse, S.M. 2018. Effect of Feeding of Bypass Fat Mineral Mixture on Productive Performance and Quality of Milk of Buffaloes in Armori Tahsil. Int.J.Curr.Microbiol.App.Sci. 7(01): 2949-2957.

doi: https://doi.org/10.20546/ijcmas.2018.701.353 